\title{
Peran Adaptive Leadership Presiden Indonesia Dalam Penanganan Covid-19 Rawan Korupsi
}

\author{
Amalia Syauket ${ }^{1, *}$ \\ ${ }^{1}$ Fakultas Hukum; Universitas Bhayangkara Jaya; Jl. Perjuangan 081, Marga Mulya, Bekasi \\ Utara, 02188955882/ +622188955871; e-mail: amalia.syauket@dsn.ubharajaya.ac.id \\ * Korespondensi: e-mail: amalia.syauket@dsn.ubharajaya.ac.id \\ Submitted: 03/06/2021; Revised: 07/06/2021; Accepted: 11/06/2021; Published: 30/09/2021
}

\begin{abstract}
The Covid-19 Handling Drama is a national leadership test event. On the other hand, society will depend on its leader and as a leader, he must meet the high expectations of himself. The Covid-19 pandemic is a threat in itself for the Government of Indonesia, if it cannot balance between encouraging economic activity (political interests) and public health (an urgent situation). This article explores the phenomenon of the central role of adaptive leadership in dealing with the Covid-19 pandemic based on constitutional rights taken to save people's lives, but the potential for corruption by using the Normative Juridical approach that prioritizes secondary data. The conclusion that can be drawn from this article is that there is no single best cure for winning this battle because the "opponent" of the current government is a growing virus. In handling the covid-19 virus pandemic, an adaptive leader is needed, namely a Leader who has authority as a consequence of the President's authority as head of state and head of government. President Joko Widodo uses his constitutional right to issue Government Regulation in Lieu of Law (Perpu) number 1 year 2020 concerning State Financial Policy and Financial System Stability for Handling the 2019 Corona Virus Disease (COVID-19) Pandemic and / or in the Context of Facing Threats that Endanger the National Economy and / or Financial System Stability. Adaptive Leadership is a form of Adaptive Governance in Handling Covid-19 but is prone to corruption.
\end{abstract}

Keywords: Adaptive Leadership and the Constitutional Rights of the President of the Republic of Indonesia, Prone to Corruption

\begin{abstract}
Abstrak
Drama Penanganan Covid-19 adalah ajang uji kepemimpinan Nasional. Disisi lain, masyarakat akan sangat tergantung pada pemimpinnya dan sebagai seorang pemimpin, dia harus memenuhi tingginya ekspektasi terhadap dirinya. Pandemi Covid-19 merupakan ancaman tersendiri bagi Pemerintah Indonesia, bila tidak dapat menyeimbangkan antara mendorong aktivitas perekonomian (kepentingan politik) dan kesehatan public (keadaan mendesak). Artikel ini menelusuri fenomena peran sentral kepemimpinan adaptif dalam menangani pandemic covid-19 berdasarkan hak konstitusional yang diambil untuk menyelamatkan jiwa masyarakat, namun potensi korupsinya dengan menggunakan pendekatan Juridis Normatif yang mengutamakan data sekunder. Kesimpulan yang dapat ditarik dari artikel ini bahwa tidak ada satu obat yang paling mujarab untuk memenangkan pertempuran ini sebab 'lawan' pemerintah kali ini adalah virus yang terus berkembang. Dalam melakukan penanganan pandemic virus covid-19 dibutuhkan seorang pemimpin yang adaptif yaitu Leader yang mempunyai Otoritas sebagai konsekwensi dari kewenangan Presiden sebagai kepala Negara dan kepala pemerintahan .Presiden Joko Widodo menggunakan hak konstitusionalnya untuk menerbitkan Peraturan Pemerintah Pengganti Undang-undang (Perpu) nomor 1 tahun 2020 tentang Kebijakan Keuangan Negara dan Stabilitas Sistem Keuangan untuk Penanganan Pandemi Corona Virus Disease 2019 (COVID-19) dan/atau dalam Rangka Menghadapi Ancaman yang Membahayakan Perekonomian Nasional dan/atau Stabilitas Sistem Keuangan. Adaptive
\end{abstract}


Leadership ini merupakan bentuk Adaptive Governance dalam Penanganan Covid-19 namun rawan terjadinya korupsi.

Kata kunci: Adaptive Leadership dan Hak Konstitusional Presiden RI, Rawan Korupsi

\section{Pendahuluan}

Tahun 2020 adalah tahun yang tak terlupakan, karena tahun 2020 akan di ingat dan dikenang oleh seluruh warga dunia sebagai tahun paling gelap dalam sejarah kehidupan manusia. Penyebabnya adalah krisis kesehatan yang menghantam seluruh dunia yang berdampak multidimensi setelah WHO menyatakan bahwa dunia telah dilanda pandemic virus Corona varian baru yang kemudian diberi nama sebagai Coronavirus Diseases 2019 atau Covid-19 sejak 30 Januari 2020.

Berawal dari Krisis kesehatan yang meluas menjadi krisis tata kelola di berbagai Negara dalam merespon pandemic. Sejumlah pemerintahan sangat responsive ada pula yang menyangkal covid-19 telah masuk ke negaranya dan meremehkan krisis kesehatan ini karena takut akan dampak negatif bagi ekonominya. Beberapa Negara yang demokratis memiliki kesiagaan yang jauh lebih baik. Kesimpulannya, tidak ada hubungan antara rezim pemerintahan dengan keberhasilan dalam merespon penanganan covid-19 (Chandranegara, 2020). Pada umumnya, keberhasilan pemerintah dalam meratakan kurva adalah hasil dari kepemimpinan dan administrasi yang kompeten, terlepas dari berbagai rezim yang sedang dianut. Dalam penanganan Covid-19 merupakan ujian kepemimpinan Nasional. Karena dua hal yaitu pertama, karena covid-19 yang merebak di Indonesia adalah sebuah rangkaian pandemi global, yang masuk melewati batas-batas negara, yang batas-batasnya dikendalikan oleh kepemimpinan nasional. Alasan kedua, tidak mungkin menggunakan seluruh sumber daya yang ada tanpa tergantung pada kepemimpinan nasional yang responsive dan adaptif, dalam sebuah negara republik yang menganut sistem presidensial. Oleh karenanya dalam melihat penanganan dan ikhtiar untuk menanggulanginya, kecermatan pemimpin (presiden) dan birokrasinya menjadi penting.

Dengan demikian tujuan penelitian yang dituangkan dalam artikel ini untuk mengetahui peran adaptive ledership seperti apa yang diambil oleh Presiden RI Joko Widodo dalam menangani Pandemi Covid-19. Sebagai bentuk kehadiran Negara dalam melindungi masyarakatnya. Namun demikian juga untuk mengetahui rawan korupsi dari berbagai kebijakan yang diambil oleh Presiden RI terkait dengan program pemberadayaan masayarakat.

Presiden sebagai Kepala Negara dan Kepala Pemerintahan merupakan gabungan antara peran 'otoritas' yang cenderung politis dan leader yang dibutuhkan untuk mendorong perubahan yang tidak bisa memenuhi kepentingan semua stakeholders. Namun, ketika seorang leader memiliki otoritas, maka cakupan kepemimpinannya akan lebih luas karena memiliki kuasa politis.

Sudah seharusnya, dari dalam diri pribadi seorang leader, kemampuan merumuskan kebijakan yang berbasis data dan ilmu pengetahuan adalah hal yang tidak bisa ditawar. Selain 
itu, internalisasi nilai-nilai adaptif Leadership ke dalam institusi pemerintahan (Adaptive Governance) juga sangat diperlukan untuk efektivitas mitigasi Covid-19.

Permasalahan penelitian pada Artikel ini adalah bagaimana adaptif leadership Presiden RI Joko Widodo dalam penanganan pandemic covid-19 untuk menyelamatkan jiwa masyarakat. Dengan menggunakan teori (Ronald Heifetz, 2009) dan Dimana saja letak rawan korupsinya yang merupakan kajian dari kebijakan yang diambil dari peran tersebut.

\section{Metode Penelitian}

Penulisan Artikel dengan judul "Peran Adaptive Leadership Presiden RI Dalam penanganan covid-19 Rawan Korupsi" menggunakan pendekatan juridis normative,dengan mengutamakan studi Kepustakaan berdasarkan data sekunder berupa : bahan hukum primer berupa perundang-undangan, bahan hukum sekunder - buku teks terbaru terkait dengan teori Adaptive Leadership dari (Ronald Heifetz, 2009) yang dianalisis dalam artikel ini dan berbagai artikel yang telah diterbitkan di beberapa jurnal penelitian juga bahan hukum tertier yang didapat dari berbagai informasi dari internet yang relevan dengan issue yang kemudian dilakukan pembahasan yang komprehensif untuk kemudian disampaikan secara naratif.

\section{Hasil dan Pembahasan}

\subsection{Memahami Adaptive Leadership}

Ronald Heifetz (Heifetz \& Ronald, 1994) dalam buku Leadership Without Easy Answers merumuskan bahwa Kepemimpinan adalah sebuah aktivitas simultan untuk menggerakkan masyarakat agar beradaptasi dengan realita atau masalah yang menantang. Dalam perjalanannya, seorang pemimpin akan menghadapi berbagai macam masalah yang dapat dikategorikan kedalam dua tipologi yaitu masalah teknis dan adaptif, seperti tampak pada gambar 1.

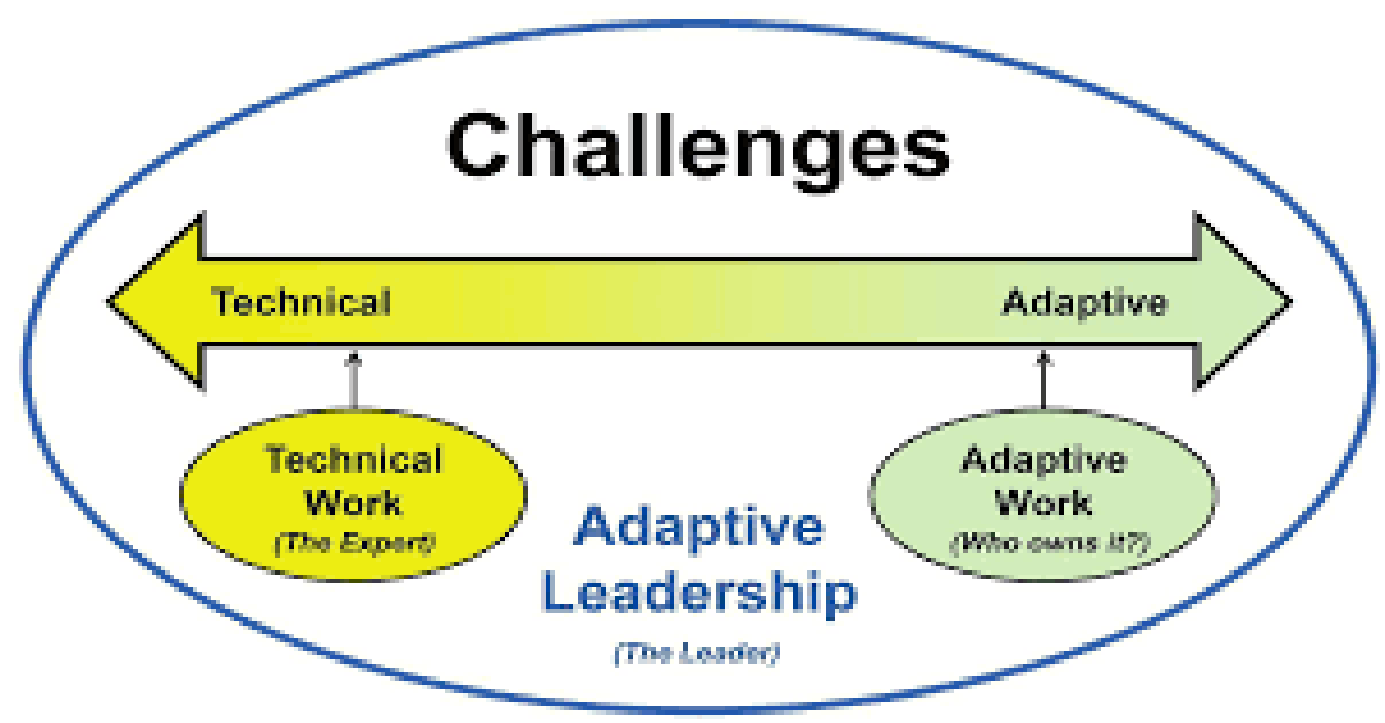

Sumber: (Anderson et al., 2015)

Gambar 1. Tipologi Adaptive 
Masalah teknis adalah masalah yang nyata di depan mata dan dapat dirumuskan strateginya untuk menentukan output yang sesuai dengan keinginan. Pekerjaan ini biasanya dapat diselesaikan oleh seseorang yang memiliki keahlian di bidang tertentu atau seorang teknokrat. Sedangkan masalah adaptif, tidak memiliki kepastian dan tidak dapat diprediksi. Hambatannya adalah adanya disparitas antara gagasan yang dibawa oleh pemimpin dengan keadaan yang terjadi tantangan terbesarnya adalah ketika mendekatkan jarak tersebut melalui penggabungkan kekuatan politik, sumber daya dan kecerdasan untuk membalikkan keadaan.

Oleh karena itu, Covid-19 merupakan ancaman tersendiri bagi pemerintah Indonesia bila tidak dapat menyeimbangkan antara aktivitas perkonomian (kepentingan politik) dan kesehatan public (keadaan mendesak). Hal ini bisa dilihat dari respon pemerintah terhadap penanganan virus corona yang memilih pendekatan teknis layaknya terlibat dalam sebuah peperangan phisik. Dengan membentuk tim percepatan penanganan virus yang ditangani oleh Menteri Kordinator bidang Maritim dan Investasi.

Masih menurut Heifetz (Heifetz et al., 2009) mengaktualisasikan adaptive leadership tidaklah mudah. Apabila dipetakan terdapat dua tantangan dari kepemimpinan adaptif yakni permasalahan yang dihadapi atau factor eksternal seperti hadirnya berbagai macam tuntutan serta adanya tarik menarik kepentingan elite politik yang alot dan keadaan dalam diri pemimpin atau factor Internal yang menjadi tantangan tersendiri bagaimana tata kelola adaptif mampu diimplementasikan untuk mencapai kepentingan bersama di bidang ekonomi dan kesehatan.

Kepemimpinan merupakan factor penting, khususnya dalam menentukan kebijakan hukum untuk menyelamatkan jiwa. Selain itu, kepemimpinan yang baik juga menetapkan kebijakan hukum yang meningkatkan dan menyederhanakan kordinasi antar kementerian maupun antara pemerintah pusat dengan provinsi. Pandemi Covid-19 perlu direspon secara efektif dengan melibatkan seluruh otoritas terkait. Pemerintah yang memiliki strategi holistic untuk menangani pasokan makanan dan kesehatan, memberikan stimulus kesejahteraan dan mengurangi perlambatan ekonomi mampu memenangkan kepercayaan dan kepatuhan public. Ini membutuhkan kepemimpinan untuk mengoptimalkan koordinasi lembaga Negara terkait (Kurlantzick, 2020).

Penanganan Pandemi Covid-19 menjadi tanggung jawab Presiden sebagai Kepala Negara dan Kepala Pemerintahan, maknanya Presiden adalah seorang Leader yang memiliki otoritas, sehingga cakupan kepemimpinannya akan lebih luas karena memiliki kuasa politis.

Pandemi Covid-19 menimbulkan ketidakpastian baik berupa waktu maupun cakupan serta dampaknya, penyebaran Covid-19 belum dapat dikendalikan meski berbagai upaya pencegahan terus dilakukan. Dalam kondisi yang seperti ini diperlukan sikap kepemimpinan yang adaptive. Yaitu kepemimpinan di tengah ketidakpastian.

\subsection{Hak Konstitusional Presiden Joko Widodo dalam Menangani Pandemi Covid-19}

Mengutip pendapat I Gede Pantja Astawa (2020) , bahwa dalam keadaan genting yang memaksa, UUD 1945 memberi kewenangan istimewa kepada Presiden untuk menyimpang dari cara bertindak dalam keadaan biasa. Yang diperkuat dengan pendapat Herman Sihombing 
(2020) mengatakan bahwa dakam kepentingan yang memaksa, supaya keselamatan Negara dapat dijamin oleh Pemerintah dalam keadaan yang genting, yang memaksa pemerintah untuk bertindak "lekas' dan 'tepat". Kedua kata ini mempunyai makna bahwa walaupun tindakannya dilakukan dengan 'Lekas"atau cepat tetapi tindakan itu harus "tepat" dan dapat dipertanggungjawabkan.

Presiden Joko Widodo menggunakan hak konstitusionalnya untuk menerbitkan Peraturan Pemerintah Pengganti Undang-undang ("Peraturan bpk," 2020) nomor 1 tahun 2020 tentang Kebijakan Keuangan Negara dan Stabilitas Sistem Keuangan untuk Penanganan Pandemi Corona Virus Disease 2019 (COVID-19) dan/atau dalam Rangka Menghadapi Ancaman yang Membahayakan Perekonomian Nasional dan/atau Stabilitas Sistem Keuangan (Ratcliffe, 2020) . DPR-RI bersama Pemerintah mensahkan Perppu nomor 1 tahun 2020 menjadi Undang-Undang nomor 2 tahun 2020 tentang Penetapan Peraturan Pemerintah Pengganti Undang-Undang Nomor 1 Tahun 2020 tentang Kebijakan Keuangan Negara dan Stabilitas Sistem Keuangan untuk Penanganan Pandemi Corona Virus Disease 2019 (Covid19) dan/atau Dalam Rangka Menghadapi Ancaman yang Membahayakan Perekonomian Nasional dan/atau Stabilitas Sistem Keuangan Menjadi Undang-Undang (Ratcliffe, 2020) Inilah salah satu bukti kehadiran Negara dalam melindungi warganya terhadap Pandemi Covid-19 di Indonesia.

Dengan demikian, hukum bernilai strategis karena menjadi instrument utama dalam merespon berbagai krisis yang ada dengan tetap berpegang teguh pada prinsip supremasi hukum. Yang juga menegaskan bahwa aturan hukum sangat penting. Dengan adanya regulasi mencerminkan kita sebagai Negara hukum harus tunduk dan patuh pada hukum yang berlaku. Sebagai Negara hukum sudah jelas bahwa segala kegiatan harus ada aturan yang mengaturnya. Hal ini menjadi dasar untuk dapat terhindar dari permasalahan hukum dikemudian hari (Barthos \& Santiago, 2020).

Dengan telah di sahkannya Perppu nomor 1 tahun 2020 menjadi Undang-Undang RI nomor 1 tahun 2020, menjadi salah satu bukti kehadiran Negara dalam melindungi warganya terhadap pandemic Covid-19 di Indonesia.Tujuan pembentukan Perppu Nomor 1 Tahun 2020, salah satunya memberi landasan hukum bagi pemerintah dalam menetapkan kebijakan dan langkah tak biasa akibat pandemi Covid-19. Dengan disahkannya Perppu itu menjadi UU diharapkan menjadi fondasi pemerintah untuk melakukan langkah luar biasa dalam menjamin kesehatan masyarakat di tengah pandemi Covid-19 (JS \& Panjaitan, 2020).

Secara Konstitusional, kesehatan dikategorikan sebagai hak asasi manusia. Sebagai hak asasi manusia, adalah kewajiban pemerintah untuk memberikan pelayanan kesehatan yang baik, serta memastikan warganya sehat. Jika hal itu dikaitkan dengan kejadian luar biasa yang disebabkan oleh Covid-19, maka kewajiban Presiden untuk menangani dan memulihkan kesehatan masyarakat itu. Sesuai dengan kewenangan istimewa yang dimiliki Presiden dalam memyelamatkan Negara dari keadaan bahaya, Presiden dapat mengambil segala tindakan dalam memulihkan kesehatan masyarakat (Hoesein, 2020). 


\subsection{Peran Sentral Kepemimpinan Adaptif Leadership Presiden Joko Widodo dalam Menangani Pandemi Covid-19 sebagai bentuk Adaptive Governance}

Presiden Joko Widodo menggunakan hak konstitusionalnya untuk menerbitkan Peraturan Pemerintah Pengganti Undang-undang (Perpu) nomor 1 tahun 2020 tentang Kebijakan Keuangan Negara dan Stabilitas Sistem Keuangan untuk Penanganan Pandemi Corona Virus Disease 2019 (COVID-19) dan/atau dalam Rangka Menghadapi Ancaman yang Membahayakan Perekonomian Nasional dan/atau Stabilitas Sistem Keuangan (Ratcliffe, 2020). Dengan diterbitkannya Perppu nomor 1 tahun 2020 telah mengubah sistim penyelenggaraan Negara yang mendasarkan pada demokrasi konstitusional berubah menjadi penyelenggaraan pemerintahan yang didasarkan pada pemusatan kekuasaan atau pemerintahan yang sentralisir (Presiden, 2020).

Asas Sentralisasi berubah menjadi asas dekonsentrasi karena perkembangan zaman dan perubahan penduduk sehingga bertambah luasnya urusan-urusan pemerintah pusat yang akibatnya pemerintah pusat menyebarkan pejabat-pejabatnya ke daerah-daerah Provinsi atas nama pemerintah pusat untuk perlindungan social dan kesejahteraan rakyat pada masa pandemic covid-19 wajib berdasarkan suatu kewenangan (Julie Mcarthy, 2020). Dengan asas desentralisasi dapat dijadikan dasar kewenangan pemerintah daerah-Kabupaten/Kota dalam memberikan bantuan dan atau program perlindungan terhadap masyarakat terdampak covid-19 di daerah-daerah.

Kemudian untuk memudahkan penanganan Covid-19, Presiden menerbitkan Keppres nomor 7 tahun 2020 tentang Gugus Tugas Percepatan Coronavirus Disease 2019 yang kemudian diubah dengan Keppres nomor 9 tahun 2020 tentang Keppres nomor 7 tahun 2020 tentang Gugus Tugas Percepatan Coronavirus Disease 2019. Gugus Tugas Percepatan Penanganan Covid-19 ini berada di bawah dan bertanggung jawab kepada Presiden (Presiden RI, 2020). Kebijakan dengan menerbitkan Keppres merupakan bentuk dari Agile Governance yang tidak lain merupakan penanganan dari berbagai ancaman akibat adanya pandemic covid 19 dari keamanan manusia secara umum.

Presiden juga menetapkan bahwa bencana non alam yang diakibatkan oleh covid-19 sebagai bencana nasional, yang penanggulangannya dilaksanakan oleh Gugus Tugas Percepatan Penanganan Covid-19 (Presiden RI, 2020)

Perlindungan social dan kesejahteraan rakyat pada masa pandemic corona-19 wajib berdasarkan suatu kewenangan yang berdasarkan pada asas-asas pemerintahan dan ketentuan perundang-undangan. Maknanya menjadi kewajiban Negara melalui organ pemerintahannya memberikan perlindungan maksimal sebagaimana amanat konstitusi sekalipun Negara dalam keadaan terserang wabah pandemic covid-19 yang mengakibatkan roda perekonomian terguncang akibatnya masyarakat kesulitan memenuhi kesejahteraan social ekonominya maka Negara wajib melindungi (Indradewi, 2020).

Pada April 2021, indeks yang dilakukan oleh Institut Lowy menempatkan Indonesia pada peringkat ke 85 dari 98 negara yang disurvey dengan mempertimbangkan kasus positif, 
angka kematian, dan jumlah tes perseribu penduduk di masing-masing Negara. Berdasarkan Peringkat tersebut Indonesia masuk dalam kategori terbaik atau cepat dalam merespon adanya Pandemi Covid-19 dan penangannya (Liputan 6.com, 2021). Maknanya, Presiden RI selaku Kepala Negara dan Kepala pemerintahan telah menjalankan perannya sebagai Adaptive Leadership yang merupakan bagian dari Adaptive Governance secara baik dalam merespon dampak dari Pandemi Covid-19.

\subsection{Rawan Korupsi Dana Bantuan Sosial Covid-19}

Dengan Keppres nomor 12 tahun 2020, diamanatkan bahwa Covid-19 adalah bencana Nasional Non Alam. Dalam Rangka Pemberdayaan bagi masyarakat korban Covid-19, Pemerintah memberikan berbagai bantuan sosial yang sepanjang tahun 2020 dalam bentuk antara lain: a) Bantuan Tunai untuk non Jabodetabek, b) Bantuan social sembako untuk Jabodetabek, c) Bantuan Tunai Langsung (BLT) Dana Desa, d) Subsidi Listrik bagi pelanggan 450KVA disebut Listrik Gratis. Sedangkan bagi pelanggan 900 KVA mendapat diskon 50\%, e) Program Keluarga Harapan (PKH), f) Kartu Sembako.

Berbagai bentuk bantuan social tersebut masuk dalam Pengadaan Barang dan Jasa yang merupakan salah satu titik rawan terjadinya tindak pidana korupsi. Komisi Pemberantasan Korupsi (KPK) telah menerbitkan Surat Edaran nomor 8 tahun 2020, yang berisi peringatan agar seluruh tahapan pelaksanaan Pengadaan barang Dan Jasa, selalu menghindari perbuatan-perbuatan yang dikatergorikan sebagai tindak pidana korupsi, diantaranya a) Tidak Melakukan persekongkolan/Kolusi dengan penyedia barang/jasa, b) Tidak memperoleh kickback dari penyedia, c) Tidak mengandung unsure penyuapan, d) Tidak mengandung unsure gratifikasi, e) Tidak mengandung unsure adanya benturan kepentingan dalam pengadaan, f) Tidak mengandungunsur kecurangan dan atau mal-administrasi, g) Tidak berniat jahat dengan memanfaatkan kondisi darurat sehingga merugikan keuangan Negara atau perekonomian Negara, h) Tidak membiarkan terjadinya tindak pidana korupsi.

Fenomena yang terjadi pada Menteri Sosial Juliari Peter Batubara yang menjadi tersangka pengadaan bantuan social (Bansos) Covid-19 dalam Operasi Tangkap Tangan KPK tanggal 5 Desemeber 2020 pukul 02.00 WIB Dini Hari antara lain a) Melakukan Persekongkolan/Kolusi dengan Penyedia Jasa dengan modus Mensos menunjuk Matheus Joko Santoso dan Adi Wahyono sebagai Pejabat Pembuat Komitmen dengan cara Penunjukan langsung rekanan, juga dengan modus berupa melakukan kontrak pekerjaan dengan supplier yang salah satunya diduga milik Matheus Joko Santoso juga melakukan pembayaran balik kepada penyelnggara Negara berupa Fee atau upah memenangkan dan komisi atau pembagian keuntungan juga pemberian hadiah atau gratifikasi. b) Menerima fee atau kickback paket Bansos sebesar Rp 10.000,- per paket sembako juga menerima Fee dari Paket Bansos Covid-19 Periode Pertama. Yang dilakukan antara penyelenggara Negara dengan penyedia barang/jasa dalam bentuk mengatur harga, mengatur pemenang seleksi pengadaan dan mengatur pembayaran balik dari penyedia. c) KPK menyebut, Mensos mengetahui langsung Penunjukan Perusahaan milik anak buahnya yang merupakan bentuk pembiaran terjadinya 
tindak pidana korupsi. Bentuk-bentuk hubungan atau relasi penyedia atau calon penyedia dengan penyelenggara Negara yang menyebabkan adanya resiko perlakukan tidak netral.

Oleh sebagian pengamat hukum dinyatakan Terdapat titik kelemahan dari Perppu nomor 1 tahun 2020 yakni: Dilindungi Pejabat Negara dalam menjalankan tugas dalam hal ini Pejabat Komite Stabilitas Sistim Keuangan (KSSK), termasuk Bank Indonesia (BI)dan Otoritas Jasa Keuangan (OJK) dan Lembaga Penjamin Simpanan (LPS) dengan hak imunitas, sehingga seluruh Penggunaan Uang Negara dalam kerangka penanganan covid-19 bukanlah kerugian Negara melainkan biaya ekonomi. Para pejabat yang terkait tersebut tidak dapat ditindak secara pidana dan produk hukumnya tidak pula dapat di gugat di PTUN. Dengan kata lain, mereka diberikan kekebalan hukum secara mutlak, baik secara pidana, perdata bahkan administrative.

Dengan demikian, seandainya benar-benar terjadi Kerugian Negara-baik yang disengaja atau tidak sengaja-termasuk kerugian Negara yang terjadi karena salah urus, atau memperkaya diri sendiri atau orang lain, menurut ketentuan ini tidak termasuk kerugian Negara karena itu tidak dapat menjadi obyek persoalan hukum.

Menurut hukum yang berlaku, Kerugian Negara antara lain bertalian dengan tindak pidana korupsi. Ketentuan dalam pasal 27 ayat (1) Perppu nomor 1 tahun 2020 mengandung makna "penghapusan atau peniadaan pertanggungjawaban hukum $c q$ pertanggung jawaban tindak pidana korupsi. Dengan perkataan lain, Undang-undang Tindak Pidana Korupsi dan ketentuan-ketentuan lain yang bertalian dengan korupsi atas keuangan Negara tidak berlaku. Dalam ungkapan lain, pasal 27 ayat (1) menciptakan imunitas atau kekebalan hukum. Pasal ini memberikan kekebalan hukum secara eksesif atau berlebihan, maknanya, Perppu ini berpeluang ditunggangi penumpang gelap, baik pemerintah atau swasta.

Namun sebagian pakar hukum berpendapat bahwa imunitas tersebut tidaklah bersifat mutlak, tetapi merupakan imunitas yang terbatas dan bersyarat antara lain dilaksanakan dengan itikat baik dan sesuai dengan ketentuan peraturan perundang-undangan. Secara a contrario, imunitas tersebut dengan sendirinya gugur apabila si pembuat kebijakan memiliki niat jahat dengan merujuk pada Putusan Mahkamah Agung nomor 42K/Kr/1965 dan perbuatannya bertentangan dengan peraturan perundangan-undangan.

Putusan Mahkamah Agung tersebut melahirkan suatu kaidah hukum, di mana sifat melawan hukum suatu tindakan hilang, bukan hanya berdasarkan ketentuan peraturan perundang-undangan, melainkan juga asas-asas keadilan atau asas-asas hukum tidak tertulis, dan bersifat umum. Misalnya, negara tidak dirugikan, kepentingan umum dilayani, dan terdakwa sendiri tidak mendapat untung. Dengan demikian, apabila kaidah tersebut dilanggar, maka pejabat yang dimaksud dalam Perppu 1/2020 tetap dapat dituntut, baik secara perdata maupun pidana. Menurut Feri Amsari (Amsari, 2021) pasal itu harus dianggap agar pejabat tidak ragu untuk bertindak demi kepentingan Negara, tetapi kalau menyimpang tetap harus dihukum. 


\section{Kesimpulan}

Sikap Adaptif Leadership Presiden Indonesia Joko Widodo sudah tepat dalam penanganan Pandemic Covid-19 untuk menyelamatkan jiwa masyarakat, yang merupakan bentuk dari Adaptive Governance karena Pandemi Covid-19 perlu direspon secara efektif dengan melibatkan seluruh otoritas terkait. Kebijakan berupa penerbitan Perppu nomor 1 tahun 2020 khususnya yang diatur dalam pasal 27 (1) sangat rawan terjadinya korupsi, mengingat besarnya anggaran Negara yang digunakan untuk mengatasi pandemic Covid-19 ini. Hak Konstitusional Presiden RI dengan menerbitkan Keppres nomor 7 tahun 2020 tentang Gugus Tugas Percepatan Penanganan Covid-19, PP nomor 21 tahun 2020 tentang Pembatasan Social Berskala Besar dalam Rangka Percepatan Penanganan Covid-19 merupakan bentuk dari Adaptive Leadership Presiden sebagai Kepala Negara dan Kepala Pemerintahan sudah tepat dan dibenarkan oleh hukum. Namun yang berlebihan dan diluar penanganan Covid-19 adalah Perppu nomor 1 tahun 2020. Untuk mengurangi angka kemiskinan tersebut sekaligus sebagai pengejawantahan amanat konstitusi untuk memajukan kesejahteraan umum maka Pemerintah mengeluarkan kebijakan pemberian bantuan sosial (yang selanjutnya disebut bansos) sebagai respon adanya kondisi pandemi saat ini. Perkuat sistim monitoring terkait dengan teknis distribusi bantuan social dalam rangka penanganan pandemic Covid-19. Perketat Pengawasan Penggunaan dan penyaluran Dana Bantuan Sosial Covid-19. Hal tersebut menunjukkan bahwa dalam penyaluran bansos oleh pemerintah saat ini terdapat sejumlah permasalahan yang menyertainya. Pada hakikatnya dalam penyaluran bansos diperlukan suatu sistem pengawasan yang ketat untuk mencegah terjadinya praktik-praktik koruptif oleh pihak yang tidak bertanggungjawab.

\section{Daftar Pustaka}

Amsari, F. (2021). Perppu stabilitas sistim keuangan dinilai rawan disalahgunakan.

Anderson, R. ., Bailey, J. D. ., Wu, C. B., Mcconnell, E. ., Thygeson, N. ., \& Docherty]. (2015). Adaptive leadership framework for chronic illness: framing a research agenda for transforming care delivery. ANS. Advances in Nursing Science, 38(2), 83.

Astawa, I. G. P. (2020). Ruang Lingkup dan Pelaksanaan Wewenang Presiden berdasarkan ketentuan pasal 22 UUD 1945. 2020.

Barthos, M., \& Santiago, F. (2020). Pandemic Covid-19 Dalam Perspektif Hukum Darurat. Jakarta: APPTHI.

Chandranegara, I. S. (2020). Diantara yang Terbaik dan Terburuk dalam merespon covid-19 di Asia Tenggara. 2020.

Heifetz, Linsky, R. A., Marty, Grashow, \& Alexender. (2009). The Practice of Adaptive Leadership; Tools and Tactics for Changing your Organization and the World,. Cambridge: Harvard Business Press.

Heifetz, \& Ronald. (1994). Leadership Without Easy Answer. Cambridge: Harvard University Press. 
Hoesein, Z. A. (2020). Zainal Arifin Hoesein, Penguatan Etika Bernegara dalam Penanganan wabah Covid-19 di Indonesia, APPTHI,Jakarta,2020. Jakarta: APPTHI.

Indradewi, A. A. S. N. (2020). Perlindungan Sosial dan kesejahteraan Rakyat pada masa pandemic covid-19 dalam perspektif konstitusi. Jakarta: APPTHI.

Ini Ranking Penanganan Covid 19 Tiap Negara di Dunia Indonesia Berapa. (2021). Liputan 6, p. 4470163.

JS, M., \& Panjaitan. (2020). Pola Penanganan Covid-19 dalam perspektif Perlindungan Hak asasi Manusia. In APPTHI.

Julie Mcarthy. (2020). Concerns in Philippine After Dutarte Given Emergency Powers to Fight Covid-19 sp- read. NPR.

Keppres nomor 12 tahun 2000 tentang Penetapan Bencana Non-Alam Penyebaran Coronavirus Disease 2019 (Covid-19) tertanggal 13 April 2020. , (2020).

Keppres nomor 7 tahun 2020 tentang Gugus Tugas Percepatan Coronavirus Disease 2019. , (2020).

Kurlantzick, J. (2020). Can Southeast Asia Fend Off the One-Two Punch of Covid-19? World Politics Review, (April), 2020.

Peraturan bpk. (2020).

Ratcliffe, R. (2020). Rebecca Ratcliffe.pdf.

Sihombing, H. (2020). Hukum Tata Negara Darurat, dalam Marojahan JS Panjaitan. Jakarta: APPTHI. 